Article

\title{
Anti-Biofilm Effects of Synthetic Antimicrobial Peptides Against Drug-Resistant Pseudomonas aeruginosa and Staphylococcus aureus Planktonic Cells and Biofilm
}

\author{
Seong-Cheol Park ${ }^{1, \dagger}{ }^{,}$Min-Young Lee ${ }^{2,+}{ }^{,}$Jin-Young Kim ${ }^{1}$, Hyeonseok Kim ${ }^{1}$, \\ Myunghwan Jung ${ }^{2}$ (D), Min-Kyoung Shin ${ }^{2}$, Woo-Kon Lee ${ }^{2}$, Gang-Won Cheong ${ }^{3}$, \\ Jung Ro Lee ${ }^{4, *(\mathbb{D})}$ and Mi-Kyeong Jang ${ }^{1,5, *}$ \\ 1 Department of Polymer Science and Engineering, Sunchon National University, Suncheon, \\ Jeonnam 57922, Korea; schpark9@gnu.ac.kr (S.-C.P.); jyfrog@hanmail.net (J.-Y.K.); hht95@naver.com (H.K.) \\ 2 Department of Microbiology, Gyeongsang National University School of Medicine, Jinju, \\ Gyeongnam 52727, Korea; mylee365@empas.com (M.-Y.L.); mjung@gnu.ac.kr (M.J.); \\ mkshin@gnu.ac.kr (M.-K.S.); wklee@gnu.ac.kr (W.-K.L.) \\ 3 Division of Applied Life Sciences and Research Institute of Natural Science, Gyeongsang National \\ University, Jinju, Gyeongnam 52828, Korea; gwcheong@gnu.ac.kr \\ 4 National Institute of Ecology, 1210 Geumgang-ro, Maseo-myeon, Seocheon-gun 33657, Korea \\ 5 The Research Institute for Sanitation and Environment of Coastal Areas, Sunchon National University, \\ Suncheon, Jeonnam 57922, Korea \\ * Correspondence: leejr73@nie.re.kr (J.R.L.); jmk8856@sunchon.ac.kr (M.-K.J.) \\ + These authors contributed equally to this work.
}

Academic Editor: Hirokazu Tamamura

Received: 16 November 2019; Accepted: 11 December 2019; Published: 12 December 2019

\begin{abstract}
Biofilm-associated infections are difficult to manage or treat as biofilms or biofilm-embedded bacteria are difficult to eradicate. Antimicrobial peptides have gained increasing attention as a possible alternative to conventional drugs to combat drug-resistant microorganisms because they inhibit the growth of planktonic bacteria by disrupting the cytoplasmic membrane. The current study investigated the effects of synthetic peptides (PS1-2, PS1-5, and PS1-6) and conventional antibiotics on the growth, biofilm formation, and biofilm reduction of drug-resistant Pseudomonas aeruginosa and Staphylococcus aureus. The effects of PS1-2, PS1-5, and PS1-6 were also tested in vivo using a mouse model. All peptides inhibited planktonic cell growth and biofilm formation in a dose-dependent manner. They also reduced preformed biofilm masses by removing the carbohydrates, extracellular DNA, and lipids that comprised extracellular polymeric substances (EPSs) but did not affect proteins. In vivo, PS1-2 showed the greatest efficacy against preformed biofilms with no cytotoxicity. Our findings indicate that the PS1-2 peptide has potential as a next-generation therapeutic drug to overcome multidrug resistance and to regulate inflammatory response in biofilm-associated infections.
\end{abstract}

Keywords: biofilm inhibition; synthetic antimicrobial peptide; drug-resistant bacteria; extracellular polymeric substances; biofilm degradation

\section{Introduction}

Biofilm consists of microorganisms embedded in a self-produced matrix of extracellular polymeric substances (EPSs) containing polysaccharides, extracellular DNA, proteins, and lipids [1-3]. The emergence of multidrug-resistant microorganisms in clinical therapeutics is a global healthcare concern. The National Institutes of Health in the USA reported that approximately $80 \%$ of chronic 
infections in humans are biofilm-related ones [4]. Infectious processes in biofilm are divided into two types, namely device- and non-device-associated infections [5]. Device-associated infections are caused by microbial colonization of medical devices such as urinary catheters, bone joints, heart valves, dental implants, prostheses, contact lenses, and endotracheal tubes [5-10]. The occurrence of nosocomial infections through biomaterials or implants is approximately $60-70 \%$; of those, 720,000 cases of central line-associated bloodstream infections occur annually in the USA via dialysis and intensive care units with an associated $12 \%$ mortality and a $\$ 45,000$ increase in treatment cost per episode [11]. Non-device-associated infections arise due to biofilm formation on tissues containing mucosal surfaces, epithelial tissues, and teeth [12-14].

Bacterial cells growing in a biofilm have physiologically different characteristics than planktonic cells of the same bacteria, and their antibiotic resistance can increase up to 1000-fold owing to the effect of self-produced EPSs. Overlong cultivation of bacterial cells imparts an adhesion ability to animal tissues and inorganic materials that enables biofilm formation. Biofilm provides a survival advantage by enhancing nutrient trapping and colonization ability compared to that of planktonic or free-floating bacteria [15]. Bacteria form biofilm in response to various factors including nutritional signals, surface attachment site recognition, exposure to sublethal antibiotic concentrations, and environmental stresses [16,17]. Generally, biofilm formation is initiated by the attachment of planktonic bacterial cells to a surface via weak van der Waals forces, followed by tighter or irreversible anchoring by pili. To facilitate the gathering and attachment of other planktonic cells, various adhesion sites are built on the matrix holding the biofilm. Bacterial cells are embedded within this EPS matrix, which is a very important target in managing biofilms and drug-resistant bacteria. During colonization, bacteria can communicate via a quorum-sensing system to facilitate biofilm development. The developed biofilms are eventually dispersed and bacteria move to other surfaces such as tissues, organs, and medical devices where these stages are repeated [16,18,19].

Pathogenic biofilm development is an important clinical concern in terms of economic losses, morbidity, and mortality; therefore, the development of anti-biofilm agents is an important factor in managing human infection. Antimicrobial peptides (AMPs) have gained increasing attention as a possible alternative to conventional drugs to combat drug-resistant microorganisms because they inhibit the growth of planktonic bacteria by disrupting the cytoplasmic membrane and inhibiting intracellular macromolecules. AMPs are considered a promising anti-biofilm agent in both drug therapies and the development of anti-infective devices. Natural AMPs are cationic, amphipathic, and 12-60 amino acids long. LL-37, a human cathelicidin peptide, has shown potent inhibitory and reductive effects against Pseudomonas aeruginosa biofilm [20] and inhibited both the surface attachment and development of Staphylococcus epidermidis biofilm [21]. P10, its analog peptide, has shown remarkable anti-biofilm activity, inhibiting biofilm development and reducing the preformed biofilm of multidrug-resistant Staphylococcus aureus [22]. CAMA, a hybrid peptide containing an N-terminus of cecropin A and melittin, effectively inhibited methicillin-resistant S. aureus (MRSA) biofilm formation [23]. Several anti-biofilm mechanisms have been discovered and include the membrane potential disruption of biofilm-embedded bacterial cells [24], the interruption of quorum-sensing systems [20], EPS reduction [25,26], alarmone system inhibition [27], and downregulation of genes related to biofilm formation and binding protein transportation [28]. Although many anti-biofilm peptides have been designed and investigated, further studies identifying and defining key amino acids and/or structural features responsible for biofilm prevention and eradication are needed.

In a previous study, we reported a potent antimicrobial activity and membranolytic mechanism of a novel peptide series with repeated sequences of "XWZX" (X: lysine or arginine, Z: leucine, tyrosine, valine, or glycine) [29]. Among eight peptides, PS1-2 ((KWYK) 3$)$ peptide with the highest therapeutic index (cell selectivity between bacteria and mammalian cells) was selected as an anti-biofilm target peptide in this study. To determine which of the lysine and arginine residues as a cationic amino acid is effective for anti-biofilm activity, PS1-5 ((RWYR $\left.)_{3}\right)$ was compared. In addition, although PS1-5 $\left((\mathrm{KWLK})_{3}\right)$ was found to be highly cytotoxic, it was chosen to compare the effects of aliphatic and 
aromatic side chains on anti-biofilm prevention. Three peptides synthesized by using a microwave peptide synthesizer were purified by $\mathrm{C}_{18}$ reversed-phase HPLC. Their anti-biofilm activity on drug-susceptible and drug-resistant P. aeruginosa and $S$. aureus cells was proved by in vitro phenotypic and EPS analyses, and by in vivo evaluation using a catheter-implanted mouse model.

\section{Results and Discussion}

\subsection{Growth Inhibition of Planktonic Cells by Peptides}

The planktonic cell growth of five P. aeruginosa and S. aureus strains was evaluated to determine the minimum inhibitory concentration (MIC) of PS1-2, PS1-5, PS1-6, and conventional antibiotics. As expected, the two conventional antibiotics (gentamicin and oxacillin) inhibited the propagation of drug-susceptible P. aeruginosa at a very low concentration; however, their MICs increased remarkably for drug-resistant P. aeruginosa (Table 1). All peptides showed potent antimicrobial activity, with MICs ranging from 4 to $1 \mu \mathrm{M}$ against five P. aeruginosa strains. Table 1 shows that PS1-2 and PS1-6 peptides significantly inhibited the growth of all tested S. aureus strains. Interestingly, MIC values of the PS1-5 peptide were $32 \mu \mathrm{M}$ for S. aureus ATCC 25923, $16 \mu \mathrm{M}$ for S. aureus CCARM 3125 and 3709, and $2 \mu \mathrm{M}$ for S. aureus DRSa 3399 and 3518, indicating that PS1-5 was more active against drug-resistant S. aureus cells than drug-susceptible cells. The arginine residue of PS1-5 binds strongly with anionic bacterial surfaces and fatty acids of phospholipid as it possesses an aliphatic straight chain that ends in a guanidino group that is protonated to result in the guanidinium form at physiological $\mathrm{pH}$. Moreover, it was found to promote the translocation of cell-penetrating peptides by guanidinium groups [30-33]. Therefore, this result may be due to an increase in peptide-binding affinity through cell-surface alterations of drug-resistant strains.

Table 1. Minimum inhibitory concentrations (MICs) of peptides and antibiotics against planktonic bacterial cells.

\begin{tabular}{ccccccc}
\hline \multirow{2}{*}{ Bacteria } & \multicolumn{7}{c}{ MIC $(\mu \mathbf{M}(\mu \mathrm{g} / \mathrm{mL}))$} \\
\cline { 2 - 6 } & PS1-2 & PS1-5 & PS1-6 & Gentamicin & Oxacillin & Erythromycin \\
\hline P. aeruginosa & & & & & \\
ATCC 15692 & $2(3.67)$ & $2(4)$ & $2(3.37)$ & $1(0.96)$ & $4(3.21)$ & - \\
CCARM 2073 & $2(3.67)$ & $2(4)$ & $2(3.37)$ & $256(244)$ & $512(411)$ & - \\
CCARM 2075 & $2(3.67)$ & $2(4)$ & $1(1.68)$ & $256(244)$ & $512(411)$ & - \\
DRPa 4007 & $4(7.34)$ & $2(4)$ & $2(3.37)$ & $512(489)$ & $256(206)$ & - \\
DRPa 3241 & $2(3.67)$ & $2(4)$ & $2(3.37)$ & $512(489)$ & $128(103)$ & - \\
S. aureus & & & & & & \\
ATCC 25923 & $4(7.34)$ & $32(64)$ & $2(3.37)$ & - & $516.42)$ & $2(1.47)$ \\
CCARM 3125 & $4(7.34)$ & $16(32)$ & $2(3.37)$ & - & $32(25.7)$ & $128(93.9)$ \\
CCARM 3709 & $2(3.67)$ & $16(32)$ & $2(3.37)$ & - & $512(411)$ & $256(188)$ \\
DRSa 3399 & $4(7.34)$ & $2(4)$ & $2(3.37)$ & - & $256(206)$ & $512(376)$ \\
DRSa 3518 & $2(3.67)$ & $2(4)$ & $2(3.37)$ & - & \\
\hline
\end{tabular}

\subsection{Inhibitory Kinetics of Peptides on Bacterial Growth}

In order to investigate the sustained AMP action, P. aeruginosa and S. aureus growth rates were investigated for $24 \mathrm{~h}$ in the presence of PS1-2, PS1-5, PS1-6, gentamicin, erythromycin, or oxacillin at their MICs (Figure 1). During 24 h of peptide incubation, the growth of drug-susceptible P. aeruginosa (ATCC 15692) and S. aureus (ATCC 25923) was significantly and continuously inhibited by all tested AMPs and antibiotics (Figure 1a,c, respectively). Figure $1 \mathrm{~b}$ shows that gentamicin and oxacillin did not inhibit P. aeruginosa CCARM 2073 growth, and the growth of S. aureus CCARM 3125 cells was not inhibited at $128 \mu \mathrm{M}$ of erythromycin and $256 \mu \mathrm{M}$ of oxacillin (Figure 1d); however, the growth of all tested bacterial strains was not detected for $24 \mathrm{~h}$ in the presence of PS1-2, PS1-5, or PS1-6. These results 
indicate that AMPs can prevent the proliferation of both drug-resistant and drug-susceptible bacteria owing to their quick and efficient bactericidal mechanisms.

a

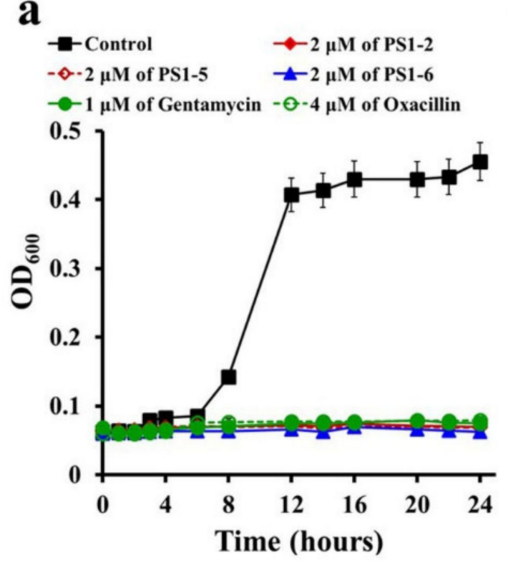

C
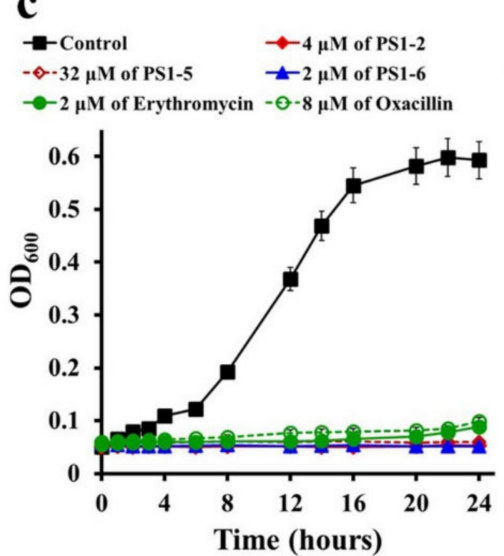

b

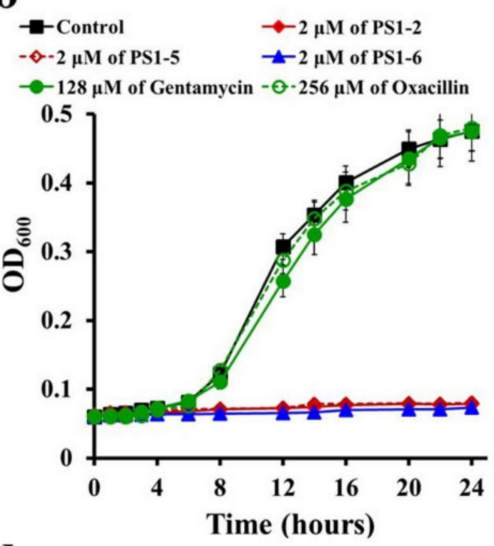

d
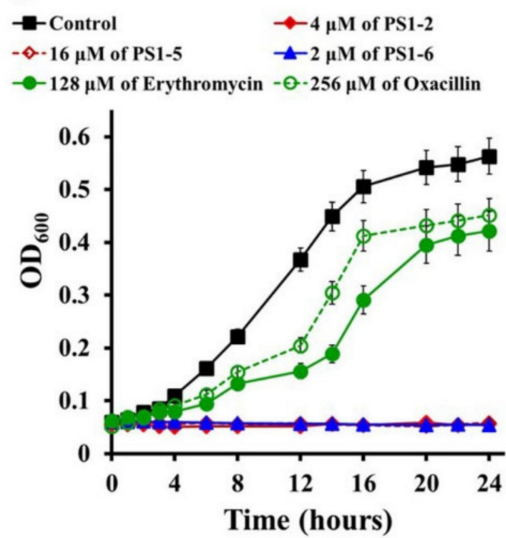

Figure 1. Growth-inhibitory kinetics of peptides and antibiotics against Pseudomonas aeruginosa (a) ATCC 15692 and (b) CCARM 2073, and Staphylococcus aureus (c) ATCC 25923 and (d) CCARM 3125 strains.

\subsection{Biofilm Formation Inhibition}

The effects of peptides in biofilm formation for P. aeruginosa (ATCC 15692, CCARM 2073, and DRPa 4007) and S. aureus (ATCC 25923, CCARM 3125, and DRSa 3518) using the crystal violet biomass staining method are shown in Figure 2. Oxacillin and erythromycin significantly inhibited the biofilm formation of drug-susceptible P. aeruginosa (ATCC 15692) and S. aureus (ATCC 25923) cells in a dose-dependent manner, respectively, at from 2 to $16 \mu \mathrm{M}$.; however, biofilm formation by drug-resistant strains (CCARM 2073 and DRPa 4007) was inhibited less than 20\% at a $64 \mu \mathrm{M}$ concentration. In contrast, all tested strains were inhibited more than $50 \%$ at an $8 \mu \mathrm{M}$ concentration in the presence of all peptides. We suggest that these biofilm-inhibitory effects may be due to inhibiting bacterial growth via bacteriocidal action of peptides or preventing attachment of bacterial cells on plate surface via cationic property of peptides. 

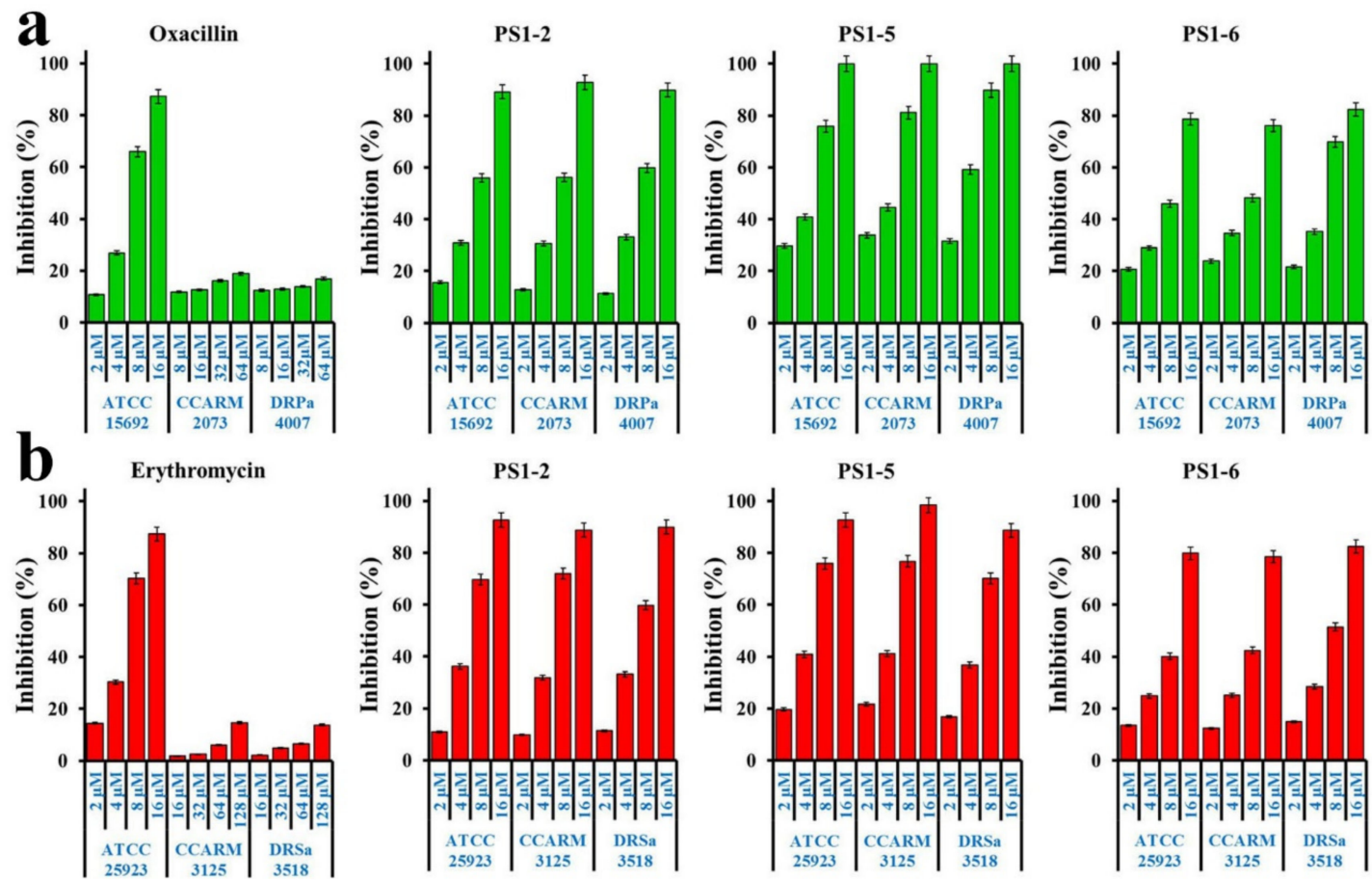

Figure 2. Inhibitory activity of peptides and antibiotics on biofilm formation of (a) P. aeruginosa and (b) S. aureus bacterial cells. (a) Oxacillin was treated at from 2 to $16 \mu \mathrm{M}$ for P. aeruginosa ATCC 15692 and from 8 to $64 \mu \mathrm{M}$ for P. aeruginosa CCARM 2073 and DRPa 4007. (b) Erythromycin was treated at from 2 to $16 \mu \mathrm{M}$ for S. aureus ATCC 25923 and from 16 to $128 \mu \mathrm{M}$ for S. aureus CCARM 3125 and DRSa 3518. Peptides ranged from 2 to $16 \mu \mathrm{M}$ and were incubated in all tested bacteria.

\subsection{Reductive Effects of Peptides on Preformed Biofilms}

After $24 \mathrm{~h}$ of biofilm formation, different antimicrobial samples (PS1-2, PS1-5, PS1-6, gentamycin, oxacillin, or erythromycin) were added to evaluate the reductive activity on preformed biofilms, followed by an additional $24 \mathrm{~h}$ of incubation. In this assay, the amount of the treated bacteria was increased 10-fold, compared to the above inhibition assay for biofilm formation, in order to completely form a biofilm. In addition, it was required to remove the biofilm EPSs and bacteria on the well surface. Therefore, a large quantity of peptides was exposed in the preformed biofilm. As shown in Figure 3, three peptides significantly contributed to reducing the preformed biofilm in both P. aeruginosa and S. aureus strains. PS1-2 had the best removal activity, showing $43.87 \%$ and $65.6 \%$ biofilm reduction in P. aeruginosa CCARM 2073 and DRPa 4007, and 60.6\% and 59.54\% biofilm reduction in S. aureus CCARM 3125 and DRSa 3518, respectively, at a concentration of $16 \mu \mathrm{M}$.

\subsection{Effect of Peptides on Biofilm Components}

To investigate how peptide reduces bacterial biofilms, specific fluorescent dyes that are able to bind to fluorescein isothiocyanate-labeled concanavalin A (FITC-ConA) for carbohydrates-Nile red for lipids, DAPI for extracellular DNA, and SYPRO red for proteins-were applied after $24 \mathrm{~h}$ of incubation with peptides, then visualized using fluorescence microscopy (Figure 4a) and quantified using fluorescence spectrophotometry (Figure $4 \mathrm{~b}$ ). Both sets of data indicated that peptides reduced the biofilm biomass by breaking down the network structures of carbohydrates, lipids, and extracellular DNA via their amphipathic structure and cationicity. 

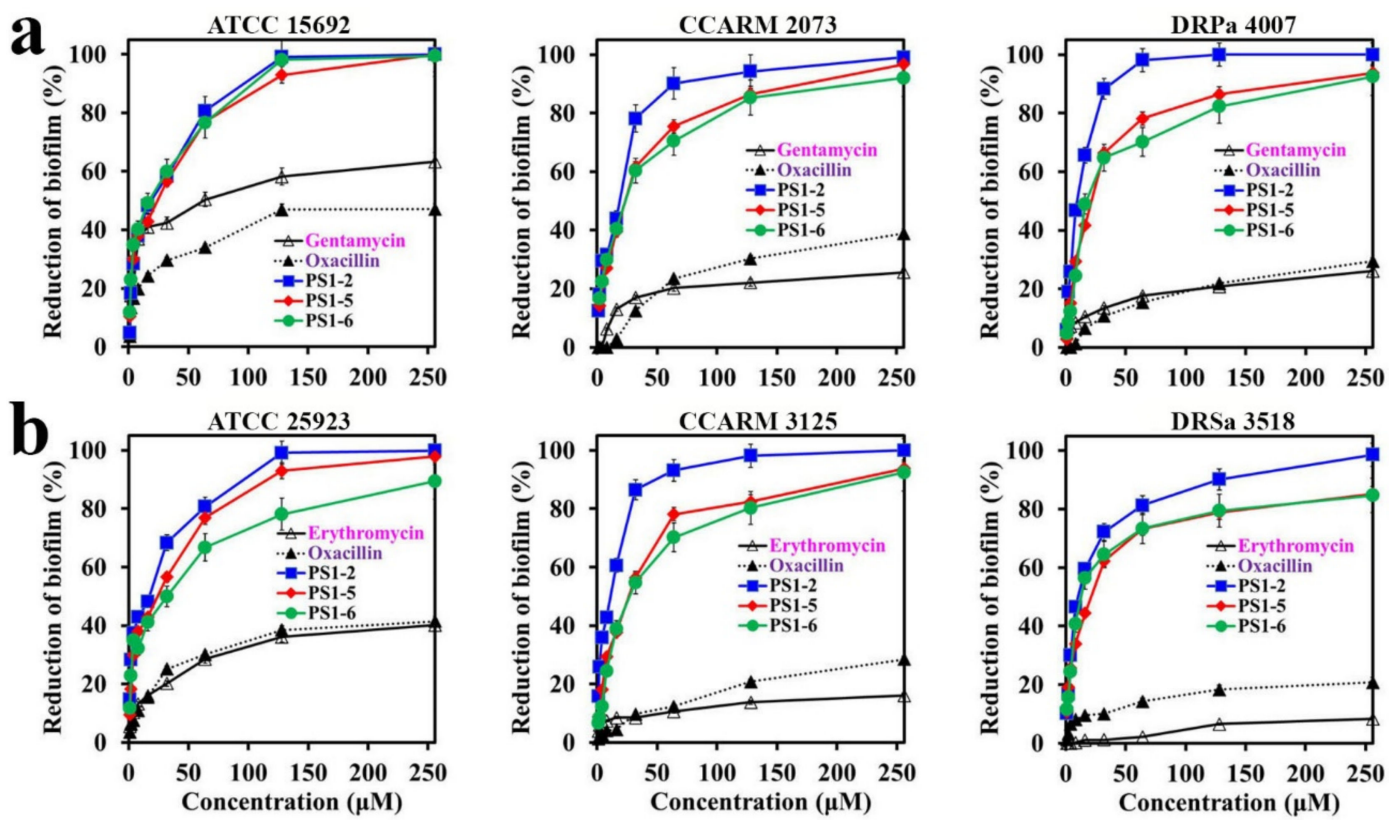

Figure 3. Reductive effect of peptides and antibiotics against preformed biofilm in (a) P. aeruginosa and (b) S. aureus bacterial cells.

\subsection{Biofilm Reduction in the Presence of Peptides}

After treatment of preformed P. aeruginosa and S. aureus biofilms on a plastic disk, biofilm biomass was observed using SEM. Biofilms and bacteria were significantly reduced in the presence of PS peptides (Figure 5). The SEM images showed a significant volume of P. aeruginosa DRPa 4007 biofilm (Figure 5a, control) and S. aureus DRSa 3125 biofilm (Figure 5b, control) in the absence of peptides compared to those in the presence of peptides. Oxacillin- or erythromycin-treated disks showed massive biofilm formation because drug-resistant bacterial strains were used for biofilm formation.

\subsection{In Vivo Anti-Biofilm Action of PS Peptides}

To investigate the in vivo anti-biofilm activity of PS peptides, biofilm that was preformed for $36 \mathrm{~h}$ on catheter samples was subcutaneously implanted into the back of nude mice (Figure 6a), followed by injection of peptides twice daily for two days. In the untreated group, three of the four mice died within two days. One mouse survived for five days, but displayed severely swollen and blackened back skin (data not shown). Increased epidermal thickness, dermis destruction, and immune cell numbers (blue arrow in Figure $6 \mathrm{~b}$ ) were observed in the presence of peptides by histological analysis. Interestingly, all mice treated with PS peptides survived. The skin tissue of mice treated with PS1-2 peptide (Figure $6 \mathrm{~b}$, iii) recovered similarly to epidermal and dermis thickness of the control mice (Figure 6b, i). Although mice treated with PS1-5 and PS1-6 peptides survived and their skin did not appear seriously injured, the increased epidermal thickness and cell necrosis (red arrow in Figure 6b) were observed by H\&E staining (Figure $6 \mathrm{~b}$, iv and v, respectively). This is due to the previously reported cytotoxic effects of PS1-5 and PS1-6 peptides in normal cells [29]. Based on these findings, PS1-2 (KWYK) $)_{3}$ may be an interesting candidate for future drug development strategies in the field of biofilm-associated infections, as it displayed no cytotoxicity in in vitro hemolytic and cytotoxic assays. 


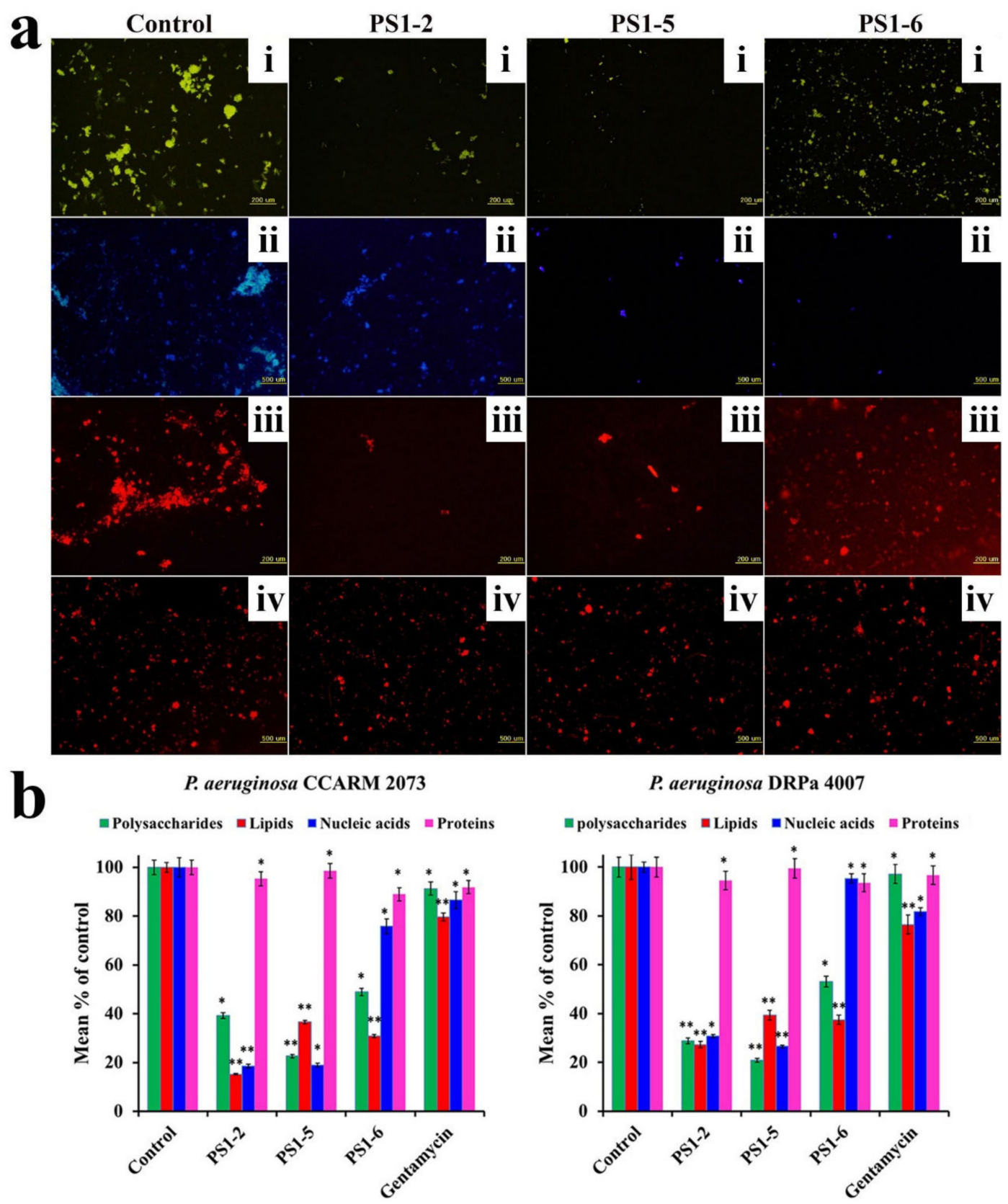

Figure 4. Eliminative action of PS peptides in biofilm extracellular polymeric substances (EPSs). (a) EPS preformed by P. aeruginosa DRPa 4007 was stained by fluorescein isothiocyanate-labeled concanavalin A (FITC-ConA) for carbohydrates (i), DAPI for nucleic acids (ii), Nile red for lipids (iii), and SYPRO red for proteins (iv) and recorded using fluorescence microscopy. (b) Eliminative percentages of PS peptides for EPS components preformed by P. aeruginosa CCARM 2073 and DRPa 4007 were evaluated by measuring fluorescence intensity. ${ }^{*}$ Indicates statistical significance compared to the control $\left({ }^{*} p<0.05\right.$; ** $p<0.001$ ). 


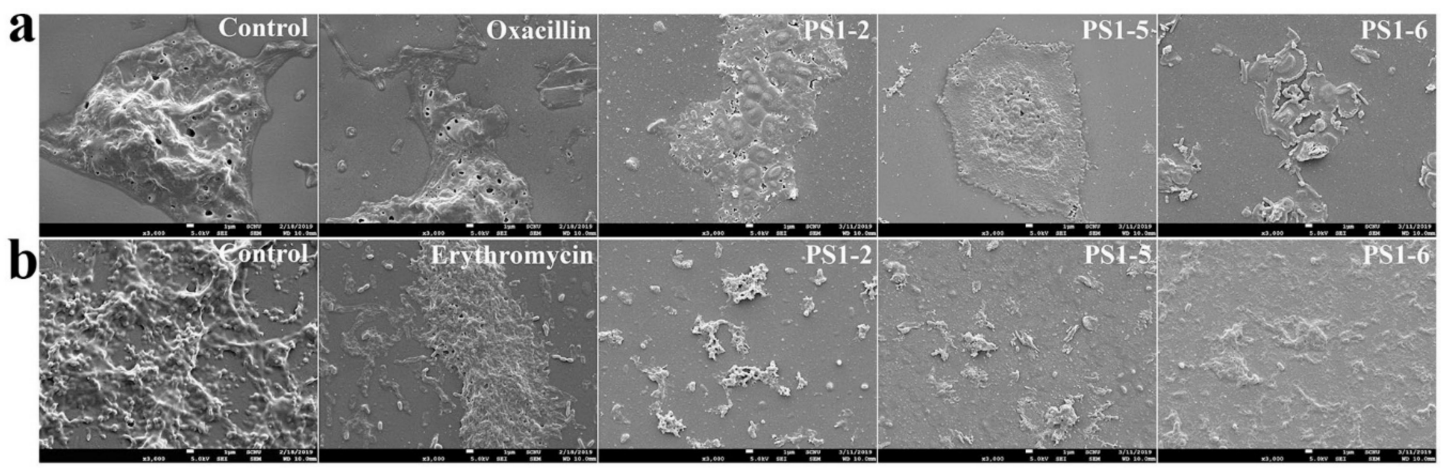

Figure 5. Reductive effects of PS peptides on biofilm preformed by P. aeruginosa DRPa 4007 (a) and S. aureus DRSa 3125 (b) on plastic disks. After biofilm formation, antibiotics or PS peptides were applied at their MICs for $24 \mathrm{~h}$.
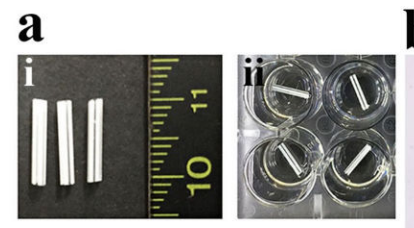

b

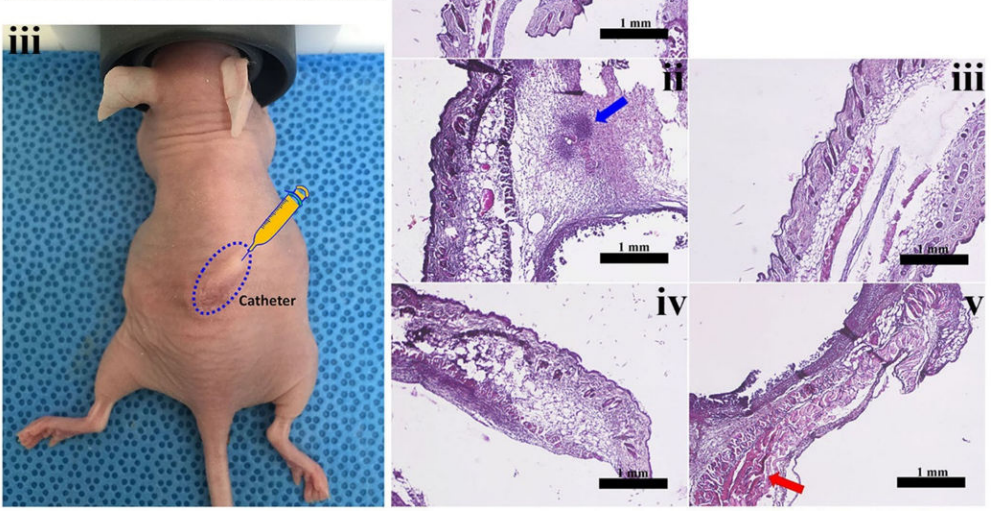

Figure 6. In vivo anti-biofilm study of PS1 peptides in the back skin of nude mice. (a) Intravenous 16G catheters (i) cut to $1 \mathrm{~cm}$ were pre-incubated in 24-well plates (ii) to which S. aureus DRSa 3125 was added for $36 \mathrm{~h}$. Catheters with biofilm formation were implanted into mouse back skin (iii) and 1 $\mathrm{mg} / \mathrm{kg}$ peptides were injected twice daily for two days. (b) Skin tissues were stained with hematoxylin and eosin and visualized using an inverted microscope. (i) control, (ii) catheter with DRSa 3125 biofilm, (iii) catheter with DRSa 3125 biofilm + PS1-2 peptide, (iv) catheter with DRSa 3125 biofilm + PS1-5 peptide, and (v) catheter with DRSa 3125 biofilm + PS1-6 peptide.

\section{Materials and Methods}

\subsection{Materials}

Oxacillin, erythromycin, gentamycin, glutaraldehyde, fluorescein isothiocyanate-labeled concanavalin A (FITC-ConA), SYPRO red, Nile red, and 4',6-diamidino-2-phenylindole (DAPI) were obtained from Sigma-Aldrich Co. (St. Louis, MO, USA). 9-Fluorenylmethoxycarbonyl (Fmoc) amino acids and Oxyma pure were purchased from CEM Co. (Matthews, NC, USA). Diisopropylcarbodiimide (DIC) and crystal violet were obtained from Tokyo Chemical Industry Co., Ltd. (Tokyo, Japan). All other chemicals and solvents were of analytical or reagent grade and used as received.

\subsection{Peptide Synthesis by Solid-Phase Method}

Microwave-assisted automated solid-phase Corporation, Matthews, NC, USA) was used (PS1-2: KWYKKWYKKWYK-CONH ${ }_{2}$, PS1-5: peptide synthesis (Liberty Blue CEM to synthesize PS1-2, PS1-5, and PS1-6 RWYRRWYRRWYR-CONH ${ }_{2}$, and PS1-6: 
KWLKKWLKKWLK-CONH 2 ). Rink Amide resin (Novabiochem) $(0.55 \mathrm{mmol} / \mathrm{g})$ was used and Fmoc deprotection was assessed by $20 \%$ piperidine in dimethylformamide (DMF). Each coupling step of Fmoc amino acids was achieved using microwave heating in the presence of DIC and Oxyma pure in DMF. Resin-synthesized peptide was transferred to a conical tube, washed with dichloromethane, and allowed to air-dry. Peptide cleavage was performed by treatment with trifluoroacetic acid (TFA)/triisopropylsilane/ $\mathrm{DiH}_{2} \mathrm{O}(95: 2.5: 2.5, v / v / v)$ for $2 \mathrm{~h}$ at room temperature. The cleaved peptide-TFA solution was precipitated with diethyl ether and then dried under a vacuum pump (Edwards RV5, Seongnam-si, Korea) to obtain a powder. The synthesized peptides were purified using a Zorbax $\mathrm{C}_{18}$ column $(21.2 \times 250 \mathrm{~mm}, 300 \AA, 7 \mu \mathrm{m})$ on a Shimadzu Preparative HPLC system (Kyoto, Japan) using 5\%-60\% acetonitrile gradient in water with $0.05 \%$ TFA. Molecular masses were confirmed using a matrix-assisted laser desorption ionization mass spectrometer (MALDI II, Kratos Analytical Ltd., Manchester, UK) [34].

\subsection{Bacterial Strains and Growth Conditions}

The anti-biofilm assay was performed using P. aeruginosa $\mathrm{PAO}_{1}$ (ATCC 15692) and S. aureus (ATCC 25923) obtained from the American Type Culture Collection (ATCC, Manassas, VA, USA). Drug-resistant P. aeruginosa (CCARM 2073 and CCARM 2075) and S. aureus (CCARM 3125 and 3709) were purchased from the Culture Collection of Antibiotic Resistant Microbes (CCARM, Seoul, Korea). Drug-resistant P. aeruginosa ((DRPa)-4007 and DRPa-3241) and drug-resistant S. aureus ((DRSa)-3399 and DRSa-3518) were clinically isolated from patients with otitis media. All strains were grown in Mueller-Hinton (MH) broth under aerobic conditions at $37^{\circ} \mathrm{C}$.

\subsection{Biofilm Susceptibility Assay}

\subsubsection{Growth Inhibition in Planktonic Bacterial Cells}

Bacterial cells were cultured at $37^{\circ} \mathrm{C}$ in $\mathrm{MH}$ broth and the antimicrobial activities of peptides for planktonic bacterial cells were determined using micro-dilution assays. Briefly, bacteria collected in the mid-log growth phase were suspended in $10 \mathrm{mM}$ sodium phosphate ( $\mathrm{pH} 7.2$ ) containing $20 \%$ $(v / v)$ brain heart infusion (BHI) broth. Two-fold serial dilutions of each peptide with concentrations ranging from 0.5 to $64 \mu \mathrm{M}$ were added to sterile 96-well plates, after which $50 \mu \mathrm{L}$ of the cell suspension $\left(1 \times 10^{6}\right.$ colony forming units $\left.(\mathrm{CFU}) / \mathrm{mL}\right)$ were added to each well. After incubation at $37^{\circ} \mathrm{C}$ for $24 \mathrm{~h}$, the turbidity of each well was measured by absorbance at $600 \mathrm{~nm}$ using a SpectraMax M5 Microplate Reader (Molecular Devices, Sunnyvale, CA, USA). The lowest concentration of peptide that completely inhibited bacterial growth was defined as the MIC; MIC values were calculated as an average of several independent experiments conducted in triplicate [35].

\subsubsection{Inhibition of Biofilm Formation Assay}

The inhibitory effect of peptides in bacterial biofilm formation was determined using 96-well plates. Pregrown bacteria were added to peptide solutions at concentrations ranging from 0.5 to $64 \mu \mathrm{M}$ in BHI broth supplemented with $2 \%(w / v)$ sucrose at a final concentration of $1 \times 10^{6} \mathrm{CFU} / \mathrm{mL}$. After incubation at $37^{\circ} \mathrm{C}$ for $24 \mathrm{~h}$, the medium was discarded and the wells were washed with phosphate-buffered saline (PBS). The biofilm was fixed with methanol for $15 \mathrm{~min}$ and air-dried at room temperature, then stained with $0.1 \%$ crystal violet for $5 \mathrm{~min}$. The wells were rinsed with water, then $200 \mu \mathrm{L}$ of $95 \%$ ethanol was added to each well and the plate was shaken at room temperature for $30 \mathrm{~min}$. Absorbance was measured at $570 \mathrm{~nm}$ on a SpectraMax M5 Microplate Reader (Molecular Devices, Sunnyvale, CA, USA) to determine biofilm biomass. Each assay was performed in triplicate.

\subsubsection{Reductive Assay in Preformed Biofilm}

Bacteria suspended in BHI broth supplemented with $2 \%(w / v)$ sucrose were adjusted to a density of $1 \times 10^{7} \mathrm{CFU} / \mathrm{mL}$ and seeded in a 96-well flat-bottomed plate, followed by incubation for $48 \mathrm{~h}$ at 
$37^{\circ} \mathrm{C}$. The wells were washed carefully with PBS, and peptides ranging from 250 to $1.95 \mu \mathrm{M}$ were added. After incubation for $24 \mathrm{~h}$ at $37^{\circ} \mathrm{C}$, the methods used for the inhibitory assay described in Section 3.4.2 were followed. Each assay was performed in triplicate.

\subsection{Growth Inhibition Kinetics}

Suspensions of P. aeruginosa PAO 1 ATCC 15692 and CCARM $2073\left(1 \times 10^{6}\right.$ CFU/mL) were added to peptide solutions in $1.5 \mathrm{~mL}$ microtubes. Bacterial cells were exposed to each of the peptides at their MICs for 0, 0.5, 1, 2, 3, 4, 6, 8, 12, 14, 16, 20, 22, and $24 \mathrm{~h}$. The samples were diluted 20-fold, then plated on $\mathrm{MH}$ agar and incubated overnight at $37^{\circ} \mathrm{C}$ before counting the colonies [35].

\subsection{Reductive EPS Analyses}

Fluorescence microplate and microscopic analyses were performed to visualize the removed EPS components. After following the processes described in Section 3.4.3, the peptide-treated biofilm was washed with PBS and stained using four fluorescent dyes $(100 \mu \mathrm{L}$ of $0.5 \mu \mathrm{g} / \mathrm{mL}$ DAPI for nucleic acids, $100 \mu \mathrm{L}$ of $1 / 500$ diluent of SYPRO red for proteins, $100 \mu \mathrm{L}$ of $20 \mu \mathrm{M}$ Nile red for lipids, and $100 \mu \mathrm{L}$ of $50 \mu \mathrm{g} / \mathrm{mL}$ FITC-ConA for carbohydrates) [36-38].

\subsection{Scanning Electron Microscopy}

Biofilm formation occurred on plastic disks (12 mm dimension, $188 \mu \mathrm{m}$ thick, SPL life science, Pocheon-si, Korea) for $36 \mathrm{~h}$, and peptides at each MIC were incubated for $24 \mathrm{~h}$. The plastic films were washed in PBS and prefixed in $1 \mathrm{~mL}$ of $5 \%(v / v)$ glutaraldehyde in PBS for $2 \mathrm{~h}$. The samples were then washed again in PBS and subsequently post-fixed in $1 \%$ osmium tetroxide (Electron Microscopy Sciences, Washington, PA, USA) for $1 \mathrm{~h}$. The samples were washed again in PBS, then dehydrated using the OTTIX shaper (Diapath S.p.A, Bergamo, Italy), dried using hexamethyldisilazane, and sputter-coated with $10 \mathrm{~nm}$ of gold. All samples were observed and photographed on an FESEM (JSM-7100F, JEOL Ltd., Tokyo, Japan) [39].

\subsection{In Vivo Study}

The in vivo animal study was performed in accordance with the protocols and guidelines approved by the Institutional Animal Care and Use Committee (IACUC) of Sunchon National University (SCNU IACUC-2019-10). Female athymic NCr-nu/nu nude mice (7 weeks old) were obtained from Koatech Co. (Pyongtaek, Gyeonggido, South Korea). Mice (four per cage and four per group) were kept in ventilated cages at $22-25^{\circ} \mathrm{C}$ with $50-60 \%$ humidity and a $12 / 12 \mathrm{~h}$ light/dark cycle. They were fed standard food (Teklad Laboratory diet for rodents) and distilled water. S. aureus DRSa 3125 was suspended in BHI broth supplemented with $2 \%(w / v)$ sucrose $\left(1 \times 10^{7} \mathrm{CFU} / \mathrm{mL}\right)$ and seeded in a 24-well flat-bottomed plate. Catheter samples (IV catheter, 16 Gauge, BD KOREA, Seoul, Korea) cut to $1 \mathrm{~cm}$ were added, followed by incubation for $36 \mathrm{~h}$ at $37^{\circ} \mathrm{C}$. Catheter samples with preformed biofilm were implanted into the skin on the back of the test mice. Mice were anesthetized by inhalation of $5 \%$ (induction) and $2 \%$ (maintenance) isoflurane in pure oxygen. DERMABOND (Ethicon, Somerville, NJ, USA) was used for wound closure. After $12 \mathrm{~h}$, peptides were injected into the lumen of the catheter with $1 \mathrm{mg} / \mathrm{kg}$ (one injection each day for two days). Five days after the last peptide injection, untreated and treated animal groups were euthanized with $\mathrm{CO}_{2}$ and the tissues around the catheter were harvested. Histological analysis was performed by hematoxylin and eosin (H\&E) staining. Briefly, tissues were washed with PBS, followed by fixation in $4 \%$ paraformaldehyde for $24 \mathrm{~h}$ at $4{ }^{\circ} \mathrm{C}$, dehydration through a $50-100 \%$ ethanol series for $2 \mathrm{~h}$ each, and bathing three times in xylene for $20 \mathrm{~min}$ each. The paraffin-embedded samples were sectioned at a thickness of $5 \mu \mathrm{m}$ (Leica microtome, Deerfield, IL, USA), followed by H\&E staining and microscopic observation (IX71, Olympus, Tokyo, Japan). 


\subsection{Statistical Analysis}

The mean values of at least three independent determinations \pm SD and the $p$-values (Student's $t$-test) were calculated using Excel software.

\section{Conclusions}

In summary, this study showed that the de novo designed AMPs PS1-2, PS1-5, and PS1-6 have an inhibiting effect on biofilm formation and disrupting activity for preformed biofilms in drug-susceptible and drug-resistant P. aeruginosa and S. aureus strains. Moreover, all PS peptides reduced the biofilm by detaching the carbohydrates, nucleic acids, and lipids of the EPS but did not detach the proteins. Future studies should focus on the use of PS1-2 as treatment for antibiotic resistant bacteria because it shows good efficacy without the risk of cytotoxicity.

Author Contributions: Conceptualization, S.-C.P., M.-Y.L., J.R.L., and M.-K.J.; Data curation, S.-C.P., M.-Y.L., J.-Y.K., and J.R.L.; Formal analysis, S.-C.P., M.J., M.-K.S., W.-K.L., G.-W.C., J.R.L., and M.-K.J.; Funding acquisition, S.-C.P.; Investigation, S.-C.P., M.-Y.L., J.-Y.K., H.K., and J.R.L.; Methodology, S.-C.P., G.-W.C., and M.-K.J.; Project administration, S.-C.P. and M.-K.J.; Supervision, S.-C.P., J.R.L., and M.-K.J.; Visualization, S.-C.P. and M.-Y.L.; Writing - original draft, S.-C.P. and M.-Y.L.; Writing—review and editing, M.J., M.-K.S., W.-K.L., J.R.L., and M.-K.J.

Funding: This research was supported by the Basic Science Research Program through the National Research Foundation of Korea funded by the Ministry of Education, Science and Technology (NRF-2016R1D1A3A03918533 and NRF-2019R1I1A3A01062547).

Conflicts of Interest: The authors declare no conflict of interest.

\section{References}

1. Gomes Von Borowski, R.; Gnoatto, S.C.B.; Macedo, A.J.; Gillet, R. Promising antibiofilm activity of peptidomimetics. Front. Microbiol. 2018, 9, 2157. [CrossRef] [PubMed]

2. Petchiappan, A.; Chatterji, D. Antibiotic resistance: Current perspectives. ACS Omega 2017, 2, 7400-7409. [CrossRef] [PubMed]

3. Yasir, M.; Willcox, M.D.P.; Dutta, D. Action of antimicrobial peptides against bacterial biofilms. Materials 2018, 11, 2468. [CrossRef] [PubMed]

4. Jamal, M.; Ahmad, W.; Andleeb, S.; Jalil, F.; Imran, M.; Nawaz, M.A.; Hussain, T.; Ali, M.; Rafiq, M.; Kamil, M.A. Bacterial biofilm and associated infections. J. Chin. Med. Assoc. 2018, 81, 7-11. [CrossRef] [PubMed]

5. Romling, U.; Kjelleberg, S.; Normark, S.; Nyman, L.; Uhlin, B.E.; Akerlund, B. Microbial biofilm formation: A need to act. J. Intern. Med. 2014, 276, 98-110. [CrossRef] [PubMed]

6. Costerton, J.W.; Montanaro, L.; Arciola, C.R. Biofilm in implant infections: Its production and regulation. Int. J. Art. Organs 2005, 28, 1062-1068. [CrossRef]

7. Pelling, H.; Nzakizwanayo, J.; Milo, S.; Denham, E.L.; MacFarlane, W.M.; Bock, L.J.; Sutton, J.M.; Jones, B.V. Bacterial biofilm formation on indwelling urethral catheters. Lett. Appl. Microbiol. 2019, 68, 277-293. [CrossRef]

8. Khatoon, Z.; McTiernan, C.D.; Suuronen, E.J.; Mah, T.F.; Alarcon, E.I. Bacterial biofilm formation on implantable devices and approaches to its treatment and prevention. Heliyon 2018, 4, e01067. [CrossRef]

9. Hao, Y.; Huang, X.; Zhou, X.; Li, M.; Ren, B.; Peng, X.; Cheng, L. Influence of dental prosthesis and restorative materials interface on oral biofilms. Int. J. Mol. Sci. 2018, 19, 3157. [CrossRef]

10. Zimmerli, W.; Sendi, P. Orthopaedic biofilm infections. Apmis 2017, 125, 353-364. [CrossRef]

11. Rupp, M.E.; Majorant, D. Prevention of vascular catheter-related bloodstream infections. Infect. Dis. Clin. North Am. 2016, 30, 853-868. [CrossRef]

12. Hardy, L.; Cerca, N.; Jespers, V.; Vaneechoutte, M.; Crucitti, T. Bacterial biofilms in the vagina. Res. Microbiol. 2017, 168, 865-874. [CrossRef] [PubMed]

13. Kriebel, K.; Hieke, C.; Müller-Hilke, B.; Nakata, M.; Kreikemeyer, B. Oral Biofilms from symbiotic to pathogenic interactions and associated disease-Connection of periodontitis and rheumatic arthritis by peptidylarginine deiminase. Front. Microbiol. 2018, 9, 53. [CrossRef] 
14. Kolenbrander, P.E.; Jr Palmer, R.J.; Periasamy, S.; Jakubovics, N.S. Oral multispecies biofilm development and the key role of cell-cell distance. Nat. Rev. Microbiol. 2010, 8, 471-480. [CrossRef] [PubMed]

15. Flemming, H.C.; Wingender, J.; Szewzyk, U.; Steinberg, P.; Rice, S.A.; Kjelleberg, S. Biofilms: An emergent form of bacterial life. Nat. Rev. Microbiol. 2016, 14, 563-575. [CrossRef] [PubMed]

16. Park, S.C.; Park, Y.; Hahm, K.S. The role of antimicrobial peptides in preventing multidrug-resistant bacterial infections and biofilm formation. Int. J. Mol. Sci. 2011, 12, 5971-5992. [CrossRef] [PubMed]

17. Petrova, O.E.; Sauer, K. Sticky situations: Key components that control bacterial surface attachment. J. Bacteriol. 2012, 194, 2413-2425. [CrossRef]

18. Jiang, Q.; Chen, J.; Yang, C.; Yin, Y.; Yao, K. Quorum Sensing: A Prospective Therapeutic Target for Bacterial Diseases. Biomed. Res. Int. 2019, 2019, 2015978. [CrossRef]

19. Senadheera, D.; Cvitkovitch, D.G. Quorum sensing and biofilm formation by Streptococcus mutans. Adv. Exp. Med. Biol. 2008, 631, 178-188.

20. Overhage, J.; Campisano, A.; Bains, M.; Torfs, E.C.; Rehm, B.H.; Hancock, R.E. Human host defense peptide LL-37 prevents bacterial biofilm formation. Infect. Immun. 2008, 76, 4176-4182. [CrossRef]

21. Saporito, P.; Vang Mouritzen, M.; Løbner-Olesen, A.; Jenssen, H. Polysaccharide intercellular adhesin (PIA) protects Staphylococcus epidermidis against major components of the human innate immune system. Cell Microbiol. 2004, 6, 269-275.

22. Haisma, E.M.; de Breij, A.; Chan, H.; van Dissel, J.T.; Drijfhout, J.W.; Hiemstra, P.S.; El Ghalbzouri, A.; Nibbering, P.H. LL-37-derived peptides eradicate multidrug-resistant Staphylococcus aureus from thermally wounded human skin equivalents. Antimicrob. Agents Chemother. 2014, 58, 4411-4419. [CrossRef] [PubMed]

23. Mataraci, E.; Dosler, S. In vitro activities of antibiotics and antimicrobial cationic peptides alone and in combination against methicillin-resistant Staphylococcus aureus biofilms. Antimicrob. Agents Chemother. 2012, 56, 6366-6371. [CrossRef] [PubMed]

24. Pinto, S.N.; Dias, S.A.; Cruz, A.F.; Mil-Homens, D.; Fernandes, F.; Valle, J.; Andreu, D.; Prieto, M.; Castanho, M.A.R.B.; Coutinho, A.; et al. The mechanism of action of pepR, a viral-derived peptide, against Staphylococcus aureus biofilms. J. Antimicrob. Chemother. 2019, 74, 2617-2625. [CrossRef] [PubMed]

25. Brancatisano, F.L.; Maisetta, G.; Di Luca, M.; Esin, S.; Bottai, D.; Bizzarri, R.; Campa, M.; Batoni, G. Inhibitory effect of the human liver-derived antimicrobial peptide hepcidin 20 on biofilms of polysaccharide intercellular adhesin (PIA)-positive and PIA-negative strains of Staphylococcus epidermidis. Biofouling 2014, 30, 435-446. [CrossRef] [PubMed]

26. Quiles, F.; Saadi, S.; Francius, G.; Bacharouche, J.; Humbert, F. In situ and real time investigation of the evolution of a Pseudomonas fluorescens nascent biofilm in the presence of an antimicrobial peptide. BBA-biomembranes 2016, 1858, 75-84. [CrossRef]

27. Åberg, A.; Shingler, V.; Balsalobre, C. (p)ppGpp regulates type 1 fimbriation of Escherichia coli by modulating the expression of the site-specific recombinase FimB. Mol. Microbiol. 2006, 6, 1520-1533. [CrossRef]

28. Hinsa, S.M.; Espinosa-Urgel, M.; Ramos, J.L.; O'Toole, G.A. Transition from reversible to irreversible attachment during biofilm formation by Pseudomonas fluorescens WCS365 requires an ABC transporter and a large secreted protein. Mol. Microbiol. 2003, 49, 905-918. [CrossRef]

29. Lee, M.Y.; Park, S.C.; Jung, M.; Shin, M.K.; Kang, H.L.; Baik, S.C.; Cheong, G.W.; Jang, M.K.; Lee, W.K. Cell-selectivity of tryptophan and tyrosine in amphiphilic $\alpha$-helical antimicrobial peptides against drug-resistant bacteria. Biochem. Biophys. Res. Commun. 2018, 505, 478-484. [CrossRef]

30. Cutrona, K.J.; Kaufman, B.A.; Figueroa, D.M.; Elmore, D.E. Role of arginine and lysine in the antimicrobial mechanism of histone-derived antimicrobial peptides. FEBS Lett. 2015, 589, 3915-3920. [CrossRef]

31. Mitchell, D.J.; Kim, D.T.; Steinman, L.; Fathman, C.G.; Rothbard, J.B. Polyarginine enters cells more efficiently than other polycationic homopolymers. J. Pept. Res. 2000, 56, 318-325. [CrossRef] [PubMed]

32. Stanzl, E.G.; Trantow, B.M.; Vargas, J.R.; Wender, P.A. Fifteen years of cell-penetrating, guanidinium-rich molecular transporters: Basic science, research tools, and clinical applications. Accounts Chem. Res. 2013, 46, 2944-2954. [CrossRef] [PubMed]

33. Liu, B.R.; Huang, Y.W.; Aronstam, R.S.; Lee, H.J. Comparative mechanisms of protein transduction mediated by cell-penetrating peptides in prokaryotes. J. Membr. Biol. 2015, 248, 355-368. [CrossRef] [PubMed]

34. Park, S.C.; Kim, J.Y.; Kim, E.J.; Cheong, G.W.; Lee, Y.; Choi, W.; Lee, J.R.; Jang, M.K. Hydrophilic linear peptide with histidine and lysine residues as a key factor affecting antifungal activity. Int. J. Mol. Sci. 2018, 19, 3781. [CrossRef] 
35. Park, S.C.; Kim, J.Y.; Jeong, C.; Yoo, S.; Hahm, K.S.; Park, Y. A plausible mode of action of pseudin-2, an antimicrobial peptide from Pseudis paradoxa. BBA-biomembranes 2011, 1808, 171-182. [CrossRef]

36. Johnsen, A.R.; Hausner, M.; Schnell, A.; Wuertz, S. Evaluation of fluorescently labeled lectins for noninvasive localization of extracellular polymeric substances in Sphingomonas biofilms. Appl. Environ. Microbiol. 2000, 66, 3487-3491. [CrossRef]

37. Yang, Y.; Sreenivasan, P.K.; Subramanyam, R.; Cummins, D. Multiparameter assessments to determine the effects of sugars and antimicrobials on a polymicrobial oral biofilm. Appl. Environ. Microbiol. 2006, 72, 6734-6742. [CrossRef]

38. Chen, M.; Lee, D.; Tay, J.; Show, K. Staining of extracellular polymeric substances and cells in bioaggregates. Appl. Microb. Biotechnol. 2007, 75, 467-474. [CrossRef]

39. Park, S.C.; Kim, I.R.; Hwang, J.E.; Kim, J.Y.; Jung, Y.J.; Choi, W.; Lee, L.; Jang, M.K.; Lee, J.R. Functional mechanisms underlying the antimicrobial activity of the Oryza sativa Trx-like protein. Int. J. Mol. Sci. 2019, 20, 1413. [CrossRef]

Sample Availability: Not available.

(C) 2019 by the authors. Licensee MDPI, Basel, Switzerland. This article is an open access article distributed under the terms and conditions of the Creative Commons Attribution (CC BY) license (http://creativecommons.org/licenses/by/4.0/). 